GRASAS Y ACEITES 69 (3)

July-September 2018, e265

ISSN-L: 0017-3495

https://doi.org/10.3989/gya.0103181

\title{
Approaches to improve the growth of the starter lactic acid bacterium OM13 during the early stages of green Spanish-style table olive production
}

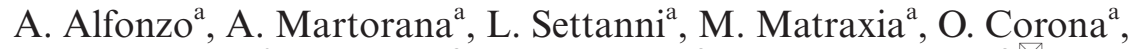 \\ P. Vagnolic, T. Caruso ${ }^{a}$, G. Moschetti a and N. Francesca, ${ }^{\mathrm{a}, \bigotimes}$ \\ ${ }^{a}$ Dipartimento Scienze Agrarie e Forestali, Università degli Studi di Palermo, Viale delle Scienze 4, 90128 Palermo, Italy \\ ¿Lallemand Italia, Via Rossini 14/B 37060 Castel D’Azzano (VR) Italy \\ ${ }^{\square}$ Corresponding author: nicola.francesca@unipa.it
}

Submitted: 09 January 2018; Accepted: 30 April 2018

\begin{abstract}
SUMMARY: The present research aimed at determining the optimal conditions for the lactic acid fermentation of green Spanish-style table olives. The work is a follow-up, and focuses on the performance of the commercial starter strain Lactobacillus pentosus OM13 by applying an acclimatization step and the addition of nutrients, and concentrations of lactic acid that were previously investigated. The acclimatization of the cells warranted the dominance of the starter culture even at an inoculation level of 2 Log cycles lower than that commonly used in standard fermentation. A significant effect was found in terms of acidification kinetics within the first week of fermentation, with the highest decrease in $\mathrm{pH}$, at $\sim 2.5$ units, which occurred in the trial and after inoculation with $10^{6} \mathrm{CFU} / \mathrm{mL}$ of starter after acclimatation (EO3) that showed values similar to control $\mathrm{C}$ obtained with Lactobacillus pentosus OM13 at a concentration of $10^{7} \mathrm{CFU} / \mathrm{mL}$. After day 3, further decreases in $\mathrm{pH}$ of up to 4.30 were observed until day 30 , and then these values remained almost constant until the end of process (day 190) when lower $\mathrm{pH}$ values were reached for trial EO3 and control $\mathrm{C}$. The results of microbiological dynamics, the changes in VOCs and finally the effect of the processes on the sensory analysis of the fermented product were investigated by multivariate analysis. The acclimatization process and the initial inoculation level influenced the bacterial microflora, aromatic compounds and organoleptic characteristics of the final product. Finally, the trials C, EO2 and EO3 showed higher values (60-80\%) of preferences and satisfaction compared to other experimental productions.
\end{abstract}

KEYWORDS: Fermentation; Food Microbiology; Olive; Sensory Evaluation; Starter Cultures

RESUMEN: Aproximaciones para mejorar el crecimiento de bacterias lácticas iniciadoras OM13 durante las primeras etapas de producción de aceitunas verdes de mesa estilo español. La presente investigación tuvo como objetivo establecer las condiciones óptimas para la fermentación láctica de aceitunas verdes de mesa estilo español. El trabajo se centra en el seguimiento del rendimiento de la cepa iniciadora comercial Lactobacillus pentosus OM13 aplicando una etapa de aclimatación, adición de nutrientes y concentraciones de ácido láctico que fueron previamente investigadas. La aclimatación de las células garantizó la dominancia del cultivo iniciador, incluso a un nivel de inoculación 2 ciclos Log menor que el utilizado habitualmente en una fermentación estándar. Se encontró un efecto significativo en términos de cinéticas de acidificación en la primera semana de fermentación, donde el mayor descenso de $\mathrm{pH}$ de $\sim 2,5$ unidades ocurrió en el ensayo inoculado con $10^{6} \mathrm{CFU} / \mathrm{mL}$ del iniciador después de la aclimatación (EO3), que mostró valores similares al control C obtenido con Lactobacillus pentosus 
OM13 a la concentración de $10^{7} \mathrm{CFU} / \mathrm{mL}$. Después del día 3, hasta el 30 se observaron descensos adicionales de $\mathrm{pH}$ hasta 4,30, manteniéndose casi constantes hasta el final del proceso (día 190) donde se alcanzaron los menores valores en el ensayo EO3 y el control. Los resultados de dinámicas microbiológicas, cambios en COVs y el efecto de los procesos en el análisis sensorial del producto fermentado se estudiaron mediante análisis multivariante. El proceso de aclimatación y el nivel de inoculación inicial influenciaron la microflora bacteriana, los compuestos aromáticos y las características organolépticas del producto final. Por último, los ensayos C, EO2 y EO3 mostraron un valor mayor $(60-80 \%)$ de preferencias y satisfacción comparada con otras producciones experimentales.

PALABRAS CLAVE: Aceituna; Cultivos iniciadores; Evaluación sensorial; Fermentación; Microbiología de Alimentos

ORCID ID: Alfonzo A https://orcid.org/0000-0002-7905-9480, Martorana A https://orcid.org/0000-0003-0646-6066, Settanni L https://orcid.org/0000-0001-7019-3598, Matraxia M https://orcid.org/0000-0003-2353-8551, Corona O https://orcid.org/0000-0002-6432-7681, Vagnoli P https://orcid.org/0000-0001-5664-1016, Caruso T https://orcid. org/0000-0002-6909-7723, Moschetti G https://orcid.org/0000-0003-0218-5769, Francesca N https://orcid.org/ 0000-0002-6063-0130

Citation/Cómo citar este artículo: Alfonzo A, Martorana A, Settanni L, Matraxia M, Corona O, Vagnoli P, Caruso T, Moschetti G, Francesca N. 2018. Approaches to improve the growth of starter lactic acid bacterium OM13 during the early stages of green Spanish-style table olive production. Grasas Aceites 69 (3), e265. https://doi.org/10.3989/ gya. 0103181

Copyright: (C2018 CSIC. This is an open-access article distributed under the terms of the Creative Commons Attribution 4.0 International (CC BY 4.0) License.

\section{INTRODUCTION}

The use of starter cultures to ferment foods and especially for table olives (De Castro et al., 2002; Francesca et al., 2016; Servili et al., 2006) is very important, as it reduces the probability of spoilage and makes fermentation a predictable and controllable process (Martorana et al., 2015, 2017a; Panagou et al., 2003).

Holzapfel (2002) defined the starter culture as a preparation containing a high number of viable cells that can be used to improve a given fermentation process. Generally, in the production of table olives it is important that the starter culture has rapid growth, a homofermentant metabolism, ability to acidify, $\mathrm{NaCl}$ tolerance, ability to grow at low temperatures, and ability to dominate the indigenous microbial populations. Moreover, the starter culture must show a high ability to withstand freezing or freeze-drying in order to facilitate the marketing and distribution of the strain (Garrido-Fernández et al., 1997).

Starter strains might affect the aroma and flavor of the olives and inhibit the growth of spoilage microorganisms by competing with them, or by producing compounds such as bacteriocins, thus promoting a greater shelf-life of the products (Holzapfel, 2002).

For the fermentation of table olives, it is possible to use as a starter both lactic acid bacteria (LAB), among which the most widely used are Lactobacillus plantarum and Lactobacillus pentosus (Hurtado et al., 2012), and yeasts which include Wickerhamomyces anomalus, Saccharomyces cerevisiae and Pichia membranifaciens (Oliveira et al., 2017).

Starter strains are usually purchased in lyophilized form as their storage at low temperature is not required. However, the conditions of rehydration and the solution adopted to reactivate them can affect their concentration and therefore their fermentation capacity. In particular, it was observed as in Lactobacillus bulgaricus, if the speed of rehydration is slow, you get a greater vitality of the microorganism (Teixeira et al., 1995).

The creation of an ideal environment for the development of a microorganism, or its acclimatization, is a widespread practice, particularly in the wine industry. An example is given by $S$. cerevisiae that, when acclimatized, it achieves a higher viable cell count and shows a greater ability to dominate the fermentation (Kontkanen et al., 2004).

The optimal growth of starter strains is facilitated by the presence of nutrients that contain sugars, vitamins and amino acids, mainly used in the wine industry to encourage the growth of yeasts in an adverse environment caused by a low $\mathrm{pH}$, high sulfur dioxide and alcohol content (Chasseriaud et al., 2015).

During grape juice fermentation, it is possible to observe how the addition of nutrients, previously inoculated with a commercial culture of $S$. cerevisiae reduce the fermentation time, at the same time favoring a rapid strain growth compared to a grape juice not supplemented with the nutrient (Kontkanen et al., 2004). Similarly, olives inoculated with $L$. pentosus and with glucose show a rapid development of lactic acid bacteria in the first month of fermentation, resulting in a $\mathrm{pH}$ decrease and limiting the number of detectable spoilage microorganisms, compared to similar olives deprived of the nutrient (Panagou et al., 2003). To further facilitate the development of the starter, the nutrient should be added to the brine immediately after inoculation of the strain. Previous studies reported the technological performance of 
the L. pentosus OM13 both on pilot (Aponte et al., 2012; Martorana et al., 2015) and industrial scales (Martorana et al., 2017a).

The present research is a follow-up of a recently study concerning the evaluation of different conditions for the industrial production of table olives with the L. pentosus OM13 strain. In order to improve the stage of fermentation by LAB during the production of green-style table olives (cultivar Nocellara del Belice), the work was focused on the ability of the L. pentosus OM13 strain to dominate microbial populations and to acidify brine rapidly when the concentration of OM13 starter, just after the inoculum, was lower than those commonly expected. With these aims, a total of seven different experimental fermentations of table olives were investigated in a microbiological, physic-chemical and sensory analysis. The experimental fermentation was carried out by using the acclimatization of starter cells and the addition of nutrients and lactic acid.

\section{MATERIALS AND METHODS}

\subsection{Experimental fermentation of table olives and sample collection}

The fermentation of table olives was carried out using drupes from the cultivar "Nocellara del Belice" and according to the Spanish-style method. The experimental design was made up of three different trials (Figure 1). Trials EO1, EO2 and EO3 were subjected to an addition of lactic acid $(90 \% \mathrm{w} / \mathrm{v}$, Merck Millipore, Vimodrone, Italy) until the $\mathrm{pH}$ of the brine was 7.0 plus $2 \mathrm{~g} / \mathrm{kg}$ of the nutrient LBO2014 (Lallemand, Inc., Montreal, Canada), consisting of glucose, fructose and yeast autolysates for LAB nutritional requirements. Subsequently, trials EO1, EO2 and EO3 were inoculated with Lal'Olive Crispy Lactobacillus pentosus OM13 at concentrations of $10^{4}, 10^{5}$ and $10^{6} \mathrm{CFU} / \mathrm{mL}$, respectively. The starter culture was used in freeze-dried form (Lallemand,

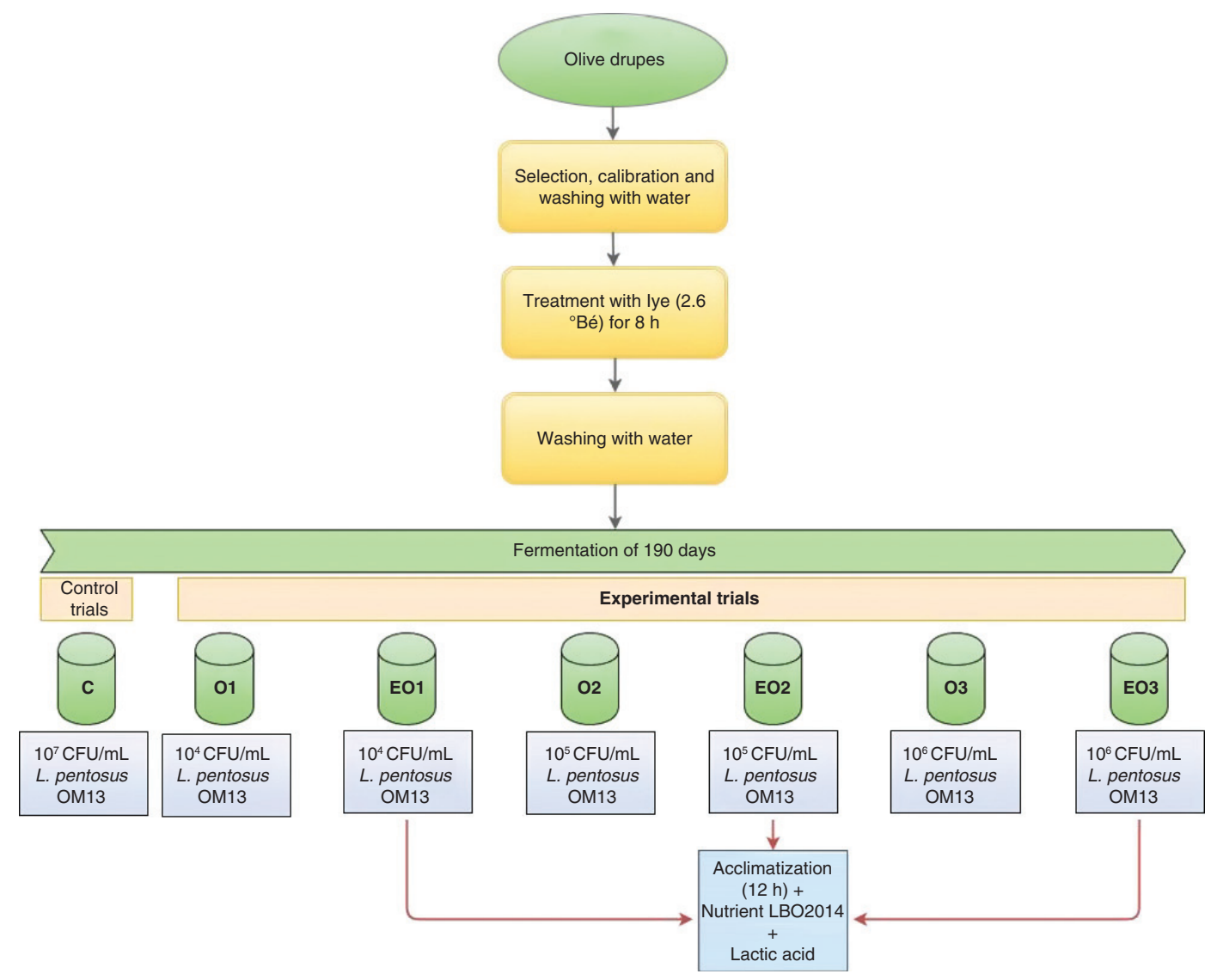

FIGURE 1. Experimental design for manufacturing of green table olives.

Abbreviation: ${ }^{\circ}$ Bé. Grade Baumé; L., Lactobacillus; C, control trial; O1, L. pentosus OM13 at $10^{4} \mathrm{CFU} / \mathrm{mL}$; EO1, L. pentosus OM13 at $10^{4} \mathrm{CFU} / \mathrm{mL}+$ Acclimatization + Nutrient LBO2014+ Lactic acid; O2, L pentosus OM13 at $10^{5} \mathrm{CFU} / \mathrm{mL} ; \mathrm{EO} 2, L$ pentosus OM13 at $10^{5} \mathrm{CFU} / \mathrm{mL}+$ Acclimatization + Nutrient LBO2014+ Lactic acid; O3, L. pentosus OM13 at $10^{6} \mathrm{CFU} / \mathrm{mL}$; EO3, L. pentosus OM13 at $10^{6} \mathrm{CFU} / \mathrm{mL}+$ Acclimatization + Nutrient LBO2014+ Lactic acid.

All experimental trials were set up in triplicate and two independent fermentations were performed in two consecutive weeks. 
Inc., Montreal, Canada), containing approximately $1.1 \times 10^{9}$ Colony-Forming Units (CFU/g) and foodgrade maltodextrin as carrier. For all experimental trials, the starter cultures, before inoculation, were subjected to an acclimatization phase in brine $(6 \%$ $\mathrm{w} / \mathrm{v} \mathrm{NaCl}$ ) for $12 \mathrm{~h}$ at room temperature. Following the manufacturer's protocol, in order to reach a concentration of $10^{7} \mathrm{CFU} / \mathrm{mL}$ of the starter in brine, a dose of $0.15 \mathrm{~g} / \mathrm{kg}$ of olives was used. The lowest dilutions $\left(10^{6}, 10^{5}, 10^{4} \mathrm{CFU} / \mathrm{mL}\right)$ were obtained by serial dilutions in the ratio of 1:10.

The experimental design also included three untreated trials $\mathrm{O} 1, \mathrm{O} 2$ and $\mathrm{O} 3$. These trials did not receive any supplement and the starter culture L. pentosus OM13 was inoculated without acclimatization at $10^{4}\left(\right.$ trial O1), $10^{5}\left(\right.$ trial O2) and $10^{6}$ (trial O3) $\mathrm{CFU} / \mathrm{mL}$.

The control test (C) was fermented only with $L$. pentosus OM13 at a concentration of $10^{7} \mathrm{CFU} / \mathrm{mL}$.

All trials were fermented at room temperature in plastic vats containing $140 \mathrm{~kg}$ of drupes and $60 \mathrm{~L}$ of brine $(10 \% \mathrm{w} / \mathrm{v} \mathrm{NaCl})$. Samples of brines (approximately $50 \mathrm{~mL}$ ) were collected before the addition of starter cultures, soon after their addition and after 3, $6,9,15,30,60,140$ and $190 \mathrm{~d}$ of fermentation. All experimental trials were set up in triplicate and two independent fermentations were performed in two consecutive weeks during October 2014 at the Geolive SAS company located in Castelvetrano (Trapani province, Sicily, Italy) ( $\left.37^{\circ} 36^{\prime} 46^{\prime \prime} \mathrm{N} / 12^{\circ} 50^{\prime} 52^{\prime \prime} \mathrm{E}\right)$.

\subsection{Analysis of $\mathrm{pH}$ and microbiological counts}

The monitoring of $\mathrm{pH}$ values and analysis of mesophilic rod LAB, yeasts, Enterobacteriaceae, pseudomonads, staphylococci and coagulase-positive staphylococci (CPS) were performed as reported by Martorana et al., (2017a). All analyses were performed in triplicate.

\subsection{Isolation, grouping and identification of lactic acid bacteria}

During the processing of fermentation at different time intervals $(3,6,9,15,30,60,140$ and $190 \mathrm{~d})$ at least five colonies, all with different morphologies of presumptive LAB sharing color, shape, edge, surface, and elevation, originating from the highest plated dilutions of microbial suspensions were collected. The presumptive identification and grouping according to phenotype were performed as reported by Martorana et al., (2017a). The pure cultures were stored in broth containing $20 \%(\mathrm{v} / \mathrm{v})$ glycerol at $-80{ }^{\circ} \mathrm{C}$.

The LAB Gram positive and catalase negative were subjected to molecular analyses. In particular the DNA from LAB overnight cultures was extracted from colonies by the InstaGene Matrix kit (Bio-Rad Laboratories, Hercules, CA, USA) and stored at $-20^{\circ} \mathrm{C}$. The strains were grouped initially by random amplification of the polymorphic DNAPCR (RAPD-PCR) analysis using single primers M13, AB111 and AB106 as previously described by Gaglio et al., (2017).

The strains were identified at species level by multiplex PCR of the recA gene with speciesspecific primers for $L$. pentosus, L. plantarum and Lactobacillus paraplantarum, according to Torriani et al., (2001). One representative culture for each multiplex cluster and all strains that did not show amplification by multiplex PCR analysis were analyzed by $16 \mathrm{~S}$ rRNA gene sequencing as described by Weisburg et al., (1991).

\subsection{Determination of volatile organic compounds (VOCs)}

The analysis of VOCs was undertaken at the end of fermentation (day 190). The table olives were subjected to GC/MS analysis in order to identify the volatile organic compounds (VOCs). $0.5 \mathrm{~g}$ of drupes were homogenized and transferred to $2 \mathrm{~mL}$ vials with pierceable silicone rubber septa coated with polytetrafluoroethylene (PTFE) film. One $\mathrm{g}$ of $\mathrm{NaCl}$ was added to increase the extraction rate of volatile compounds. The extractions of VOCs were carried out using a SPME fiber of divinylbenzene/carboxen/ polydimethylsiloxane (Supelco, Bellefonte, PA) to analyze the SPME fiber as reported by Corona et al., (2016). The GC-MS system and chromatographic conditions described by Gaglio et al., (2014) were used for analysis. The detection was carried out by electron impact mass spectrometry in total ion current (TIC) mode using an ionization energy of 70 $\mathrm{eV}$. The mass acquisition range was $\mathrm{m} / \mathrm{z} 30$ to 330 . The identification of volatiles was done by injection of commercial standards and by comparing their mass spectra with those within the NIST/EPA/NIH Mass Spectral Library database (Version 2.0d, build 2005). VOCs were expressed as relative peak areas (peak area of each compound/total area) $\times 100$. Determinations were carried out in triplicate for each sample.

\subsection{Sensory evaluation}

At end of fermentation (day 190) the table olives were evaluated by 12 judges ( 6 female and 6 male, aged 20-35 years) using the method UNI 10957 (2003), which is based on the use of 16 descriptors (green color intensity, brightness, green olive aroma, complexity (odor), off-odors, crispness, easy stone detachment from the flesh, juicy, sweet, sour, bitter, salt, bitter and complexity (taste), astringent, offflavors and overall acceptability. The scale of values ranged from 1.00 (absence of sensation) to 9.00 (extremely intense). For each trial, two panel sessions were performed. Before assessing the experimental 
samples, the judges were trained using commercial table olives belonging to the Nocellara del Belice cultivar. The methodology has been described in detail by Martorana et al., (2016, 2017a).

\subsection{Statistical and explorative multivariate analyses}

Data obtained from the monitoring of $\mathrm{pH}$, microbial population, VOCs and sensory analysis were subjected to statistical analysis using a generalized linear model (GLM) based on an ANOVA model that included effects of trials and week $\left(1^{\text {st }}\right.$ and $\left.2^{\text {nd }}\right)$ of production, as well as the interaction between trials and week of production. The post-hoc Tukey method was applied for pair-wise comparison. Statistical significance was attributed to $p$ values of $<0.05$.

The resulting scores from the sensory analysis were averaged and compared. The ANOVA test was applied to identify significant differences among olive attributes.

The values of $\mathrm{pH}$ and microbial population were also analyzed by an explorative multivariate analysis. The connection among samples was determined with the agglomerative hierarchical clustering (AHC) based on level of dissimilarity (Euclidean distance) among samples. The same data set from the $\mathrm{pH}$ and microbial analysis was subjected to canonical analysis (CA) using only the variables that clustered samples into classes which resulted statistically significantly different.

The different VOCs of the table olives from different experimental trials were displayed by a heat map clustered analysis (HMCA) as reported in Martorana et al., (2017a).

The multivariate statistical analysis was concluded using the data from the sensory analysis of fermented olives which were subjected to preferences and satisfaction analyses (Jervis et al., 2016). In this analysis, in order to evaluate scores of preferences, judges were clustered into classes for the global appreciation variable which was obtained and associated with the sensory attributes of table olives. Furthermore, an AHC and a PCA of sensory scores were used to construct the external preference mapping (EPM) vector model. External preference mapping contour plots were obtained using PREFMAP within XLSTAT Addinsoft (New York, NY).

All statistical data processing and graphical constructions were carried out using XLStat software version 2014.5.03 (Addinsoft, New York, USA) for excel.

\section{RESULTS AND DISCUSSIONS}

\subsection{Monitoring of $\mathbf{p H}$}

Data concerning the $\mathrm{pH}$ changes in brines during the entire period of olive production are shown in Figure 2A. Since the manufacturing process of olives followed the Spanish style, at the beginning of the process the $\mathrm{pH}$ value was about 8.5 in trials $\mathrm{O} 1, \mathrm{O} 2, \mathrm{O} 3$ and control $\mathrm{C}$, which were not subjected to acidification by lactic acid addition. On the contrary, the experimental trials EO1, EO2 and $\mathrm{EO} 3$ were added with lactic up to $\mathrm{pH}$ 7.5. A rapid decrease in $\mathrm{pH}$ within the first week of olive manufacturing might inhibit the growth of spoilage populations thus reducing the risk of organoleptic alteration of the final product. $\mathrm{pH}$ values higher than 5 might promote the growth of several spoilage microorganisms such as enterobacteria, pseudomonads and staphylococci, which are usually hosted by olive drupes and responsible for organoleptic alterations (Martorana et al., 2017a). In addition, at high concentrations, yeasts might be responsible for the production of off-flavor (Arroyo-López et al., 2008).

The acidification kinetics of table olive and brine is closely correlated with the amount of organic acids, such as lactic and acetic acids, which are produced by LAB during the olive fermentation process. Hence, methods to promote the growth of LAB and decrease the $\mathrm{pH}$ are of paramount importance for improving the sensory quality of the final product (Martorana et al., 2017a). In the present study, the experimental design has been focused on innovative protocols to improve $\mathrm{pH}$ decrease through the growth of $\mathrm{LAB}$ also when the population of inoculated $\mathrm{LAB}$ starter is lower than $10^{7} \mathrm{CFU} / \mathrm{mL}$ of brine.

After three days of fermentation, the lowest values of $\mathrm{pH}$ (5.03) were observed in experimental trial EO3 inoculated with $10^{6} \mathrm{CFU} / \mathrm{mL}$ of starter subjected to acclimatization and supplemented with nutrients and lactic acid up to $\mathrm{pH} 7.5$ in the brine. At day 6 the trials EO2 (4.98) and EO3 (4.99) showed the lowest $\mathrm{pH}$ values. On the $9^{\text {th }}$ day the experimental productions $\mathrm{C}, \mathrm{O} 2, \mathrm{EO} 2, \mathrm{EO} 3$ showed $\mathrm{pH}$ values lower than 5; the lowest values were observed for trials C (4.31) and EO3 (4.38). Subsequently, these values remained almost constant until the end of the process (day 190) when lower $\mathrm{pH}$ values were reached in trial EO3 (4.10) and control C (4.08). The other trials $(\mathrm{O} 1, \mathrm{EO} 1, \mathrm{O} 2, \mathrm{EO} 2, \mathrm{O} 3)$ showed $\mathrm{pH}$ values between 4.34-4.65.

\subsection{Microbiological counts}

The changes in microbial populations were variable among trials and the results of counts are reported in Figure 2, b-f. During the first phase of fermentation (until the day 3), the highest levels of LAB population were reached by the experimental trials EO3 (7.41 CFU/mL) and EO2 (6.97 CFU/mL), which were higher than or superimposable to those found for the control C $(6.95$ $\mathrm{CFU} / \mathrm{mL})$. Lower LAB levels were found in trials $\mathrm{O} 1(5.11 \mathrm{CFU} / \mathrm{mL})$ and $\mathrm{O} 2(6.08 \mathrm{CFU} / \mathrm{mL})$. These trends were also observed in samples collected from 

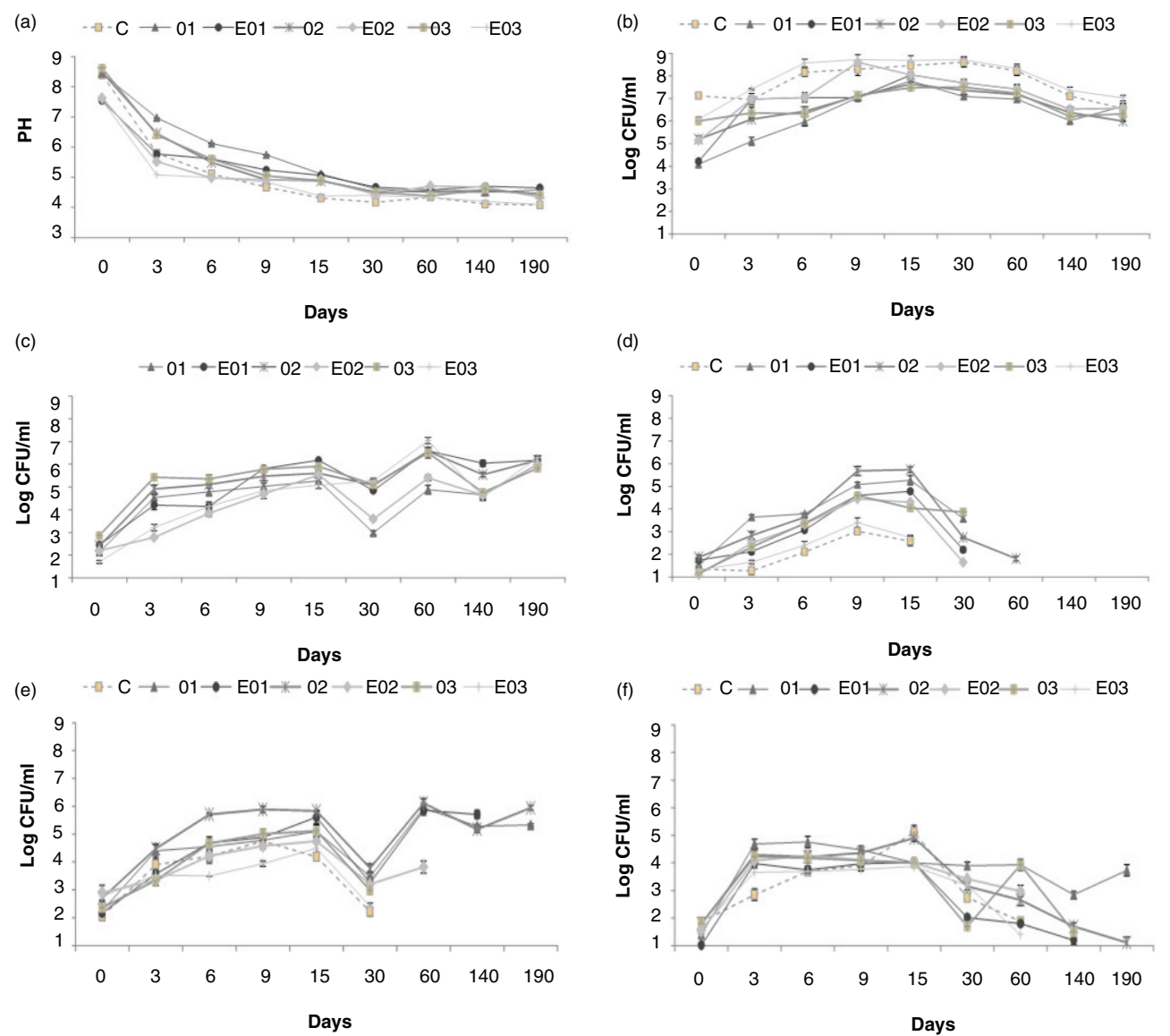

Figure 2. Values of pH changes (a) and microbial populations (b-f) of samples collected during table olive fermentation.

Results indicate the mean values of three measurements.

Abbreviations: C, control trial; O1, L. pentosus OM13 at $10^{4} \mathrm{CFU} / \mathrm{mL}$; EO1, L. pentosus OM13 at $10^{4} \mathrm{CFU} / \mathrm{mL}+$ Acclimatization + Nutrient LBO2014 + Lactic acid; O2, L. pentosus OM13 at $10^{5} \mathrm{CFU} / \mathrm{mL} ; \mathrm{EO} 2$, L. pentosus OM13 at $10^{5} \mathrm{CFU} / \mathrm{mL}+$ Acclimatization + Nutrient LBO2014 + Lactic acid; O3, L. pentosus OM13 at $10^{6} \mathrm{CFU} / \mathrm{mL} ; \mathrm{EO} 3$, L. pentosus OM13 at $10^{6} \mathrm{CFU} / \mathrm{mL}+$ Acclimatization + Nutrient LBO2014 + Lactic acid.

Letters between brackets from a to f indicate values of $\mathrm{pH}$ (a) and microbial counts of LAB on MRS (b), yeasts on DRBC (c), Enterobacteriaceae on VRBGA (d), pseudomonads on PAB (e) and staphylococci on BP (f) media.

day 6 to the end of fermentation (day 190) when trial EO3 showed 7.02 Log $(\mathrm{CFU} / \mathrm{mL})$ and control C $6.55 \log (\mathrm{CFU} / \mathrm{mL})$.

With regards to yeasts, at the beginning of process, these populations started from values of about $2.5 \mathrm{CFU} / \mathrm{mL}$ (Figure 2C) and showed a constant increase until the end of the trial when yeast counts were of about $6.0 \mathrm{CFU} / \mathrm{mL}$ in all trials. The counts performed for Enterobacteriaceae, Pseudomonadaceae and Staphylococcaceae are also reported in Figures 2D, 2E, 2F. Members of the Enterobacteriaceae family reached higher values of about $5 \mathrm{Log}(\mathrm{CFU} / \mathrm{mL})$ at day 15 in trials O2, $\mathrm{EO} 1$ and $\mathrm{O} 1$; within the same period the lowest concentrations of Enterobacteriaceae were found for experimental trial EO3 and control $\mathrm{C}$, which did not show values higher than $3 \log (\mathrm{CFU} / \mathrm{mL})$. With the exception of trial O2, Enterobacteriaceae were detectable until day 35 in all trials. Staphylococci and pseudomonad populations reached their highest concentrations of about $5 \mathrm{Log}(\mathrm{CFU} / \mathrm{mL})$ at day 15 in all trials and both populations remained at detectable levels in trials $\mathrm{O} 1$ and $\mathrm{O} 2$ until the end of the process.

In the present study, similar LAB dynamics and $\mathrm{pH}$ changes were found which support those already published by Martorana et al., (2017a) during the entire period of olive manufacturing. These authors provided evidence that the addition of lactic acid, nutrient adjuvants and, most importantly, the acclimatization of LAB cells significantly shortened the acidification process of olive brine, prevented spoilage and improved sensory quality. These results are in accordance with the data reported by De Castro et al., (2002), which showed that LAB starter cultures, grown overnight in MRS in the presence of 
$4.5 \% \mathrm{w} / \mathrm{v} \mathrm{NaCl}$, allow the cells to adapt to the stressful conditions of the brine and to dominate the fermentation process. In this study, the acclimatization process was carried out during the industrial production process of table olives through the inoculum of the strain starter in brine.

In order to find significant differences among experimental trials, the values of microbial counts and changes in $\mathrm{pH}$ were subjected to multivariate statistical analysis (Figures 3, 4 and 5). On the basis of AHC analysis (Figure 3), all trials were grouped into three classes at a dissimilarity level of $126.44 \%$. Within classes, significant differences were found in terms of variance; the experimental trial $\mathrm{EO} 3$ was closely related to control $\mathrm{C}$ and grouped into class 1 which was characterized by the lowest values for within-class variance (21.27). Trials EO2 and $\mathrm{O} 3$ were further clustered into class 2 , which showed 68.27 of within-class variance. The remaining experimental trials EO1, $\mathrm{O} 1$ and $\mathrm{O} 2$ were grouped together into class 3 , with 60.82 within-class variance.

The results from the AHC analysis, which showed the values of microbial and $\mathrm{pH}$ variables associated with each class. In particular, the variables that mainly affected the distribution of trials were $\mathrm{pH}$ values and LAB, Enterobacteriaceae and

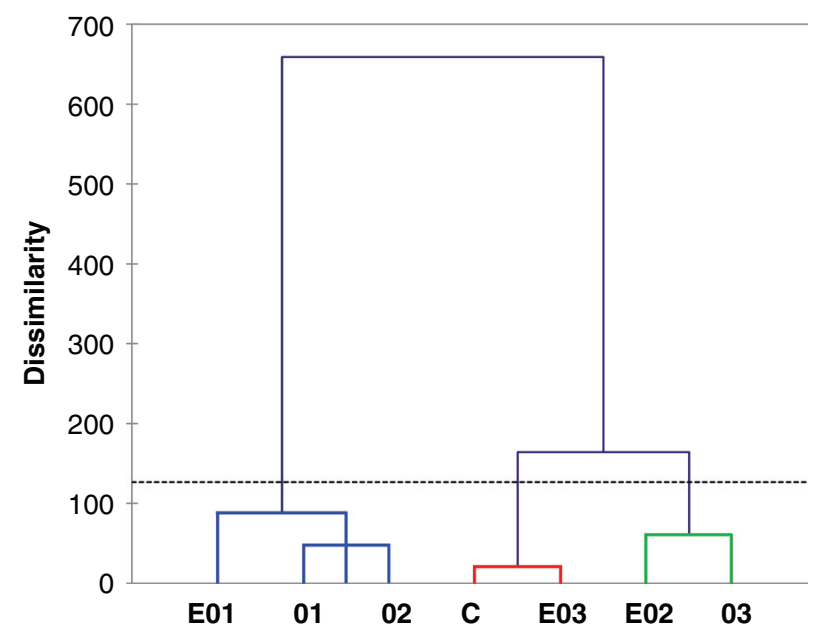

FIGURE 3. Dendrogram resulting from the agglomerative hierarchical clustering analysis based on values of $\mathrm{pH}$ and microbial populations.

Abbreviations: C, control trial; O1, L. pentosus OM13 at $10^{4} \mathrm{CFU} / \mathrm{mL}$; EO1, L. pentosus OM13 at $10^{4} \mathrm{CFU} / \mathrm{mL}+$ Acclimatization + Nutrient LBO2014 + Lactic acid; O2, L. pentosus OM13 at $10^{5} \mathrm{CFU} / \mathrm{mL}$; EO2, L. pentosus OM13 at $10^{5} \mathrm{CFU} / \mathrm{mL}+$ Acclimatization + Nutrient LBO2014 + Lactic acid; O3, L. pentosus OM13 at $10^{6} \mathrm{CFU} / \mathrm{mL}$; EO3, L. pentosus $\mathrm{OM} 13$ at $10^{6} \mathrm{CFU} / \mathrm{mL}+$ Acclimatization + Nutrient LBO2014 + Lactic acid.

The dissimilarity among samples was measured by Euclidean distance, whereas cluster aggregation was achieved by Ward's method.

The blue, red and green colors of lines indicate the three clusters into which trials are grouped pseudomonads concentrations. No significant differences were found among classes in terms of minimum and maximum values of variables.

With the aims to find correlations among the experimental treatments and physico-chemical and microbiological characteristics of table olives, the data were further investigated by explorative multivariate correspondence analysis as shown by the symmetric plot (Figure 4), which explained 88.97\% of total inertia. All experimental trials were clustered into three main clusters and they were mainly separated along Factor 1 axes, which explained $77.44 \%$ of total variability. Interestingly, a close distribution was found between trial EO3 and control $\mathrm{C} 1$, which were significantly correlated with the high values of the MRS variable. Trial EO2 was manly correlated with $\mathrm{pH}$ values and also with MRS.

On the other hand, trials $\mathrm{O} 1$ and $\mathrm{O} 2$, which were carried out without acclimatization of starter cells and adjuvants, were mainly correlated with PAB and VRBGA variables. High differences, along the $\mathrm{F} 1$ and F2 axes, were found between trials EO3 and $\mathrm{O} 3$, as well as between experimentations EO2 and $\mathrm{O} 2$. These results showed that the acclimatization procedures and addition of nutrients and lactic acid affected the kinetics of brine acidification and microbial growth, in particular that of LAB population.

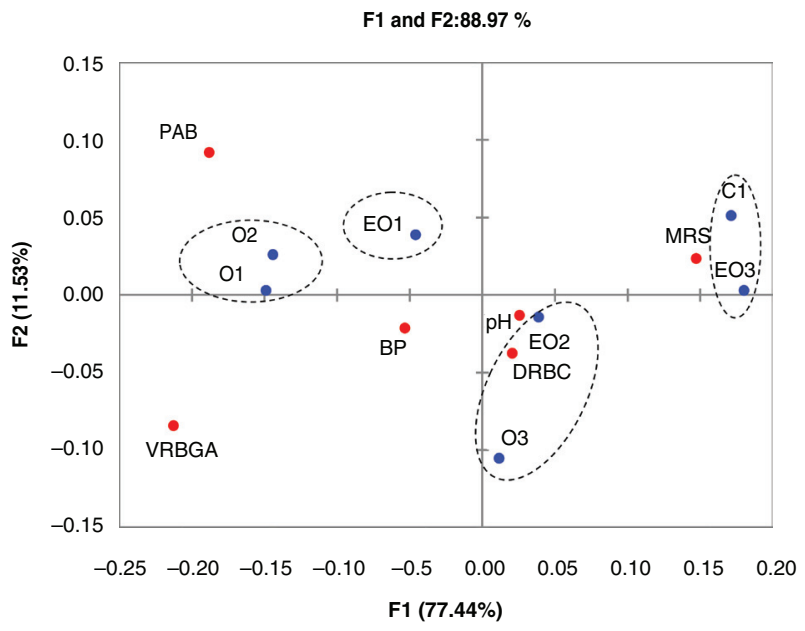

Figure 4. Symmetric plot from the canonical analysis based on values of $\mathrm{pH}$ and microbial populations.

Abbreviations: C, control trial; O1, L. pentosus OM13 at $10^{4} \mathrm{CFU} / \mathrm{mL}$; EO1, L. pentosus OM13 at $10^{4} \mathrm{CFU} / \mathrm{mL}+$ Acclimatization + Nutrient LBO2014+ Lactic acid; O2, $L$. pentosus OM13 at $10^{5} \mathrm{CFU} / \mathrm{mL}$; EO2, L. pentosus OM13 at $10^{5} \mathrm{CFU} / \mathrm{mL}+$ Acclimatization + Nutrient LBO2014+ Lactic acid; O3, L. pentosus OM13 at $10^{6} \mathrm{CFU} / \mathrm{mL}$; EO3, L. pentosus $\mathrm{OM} 13$ at $10^{6} \mathrm{CFU} / \mathrm{mL}+$ Acclimatization + Nutrient LBO2014+ Lactic acid. MRS, Man-Rogosa-Sharpe agar for mesophilic rod LAB; DRBC, dichloran rose bengal chloramphenico agar for total yeasts and filamentous fungi; VRBGA, violet red bile glucose agar for Enterobacteriaceae; PAB, Pseudomonas agar base for Pseudomonadaceae. 


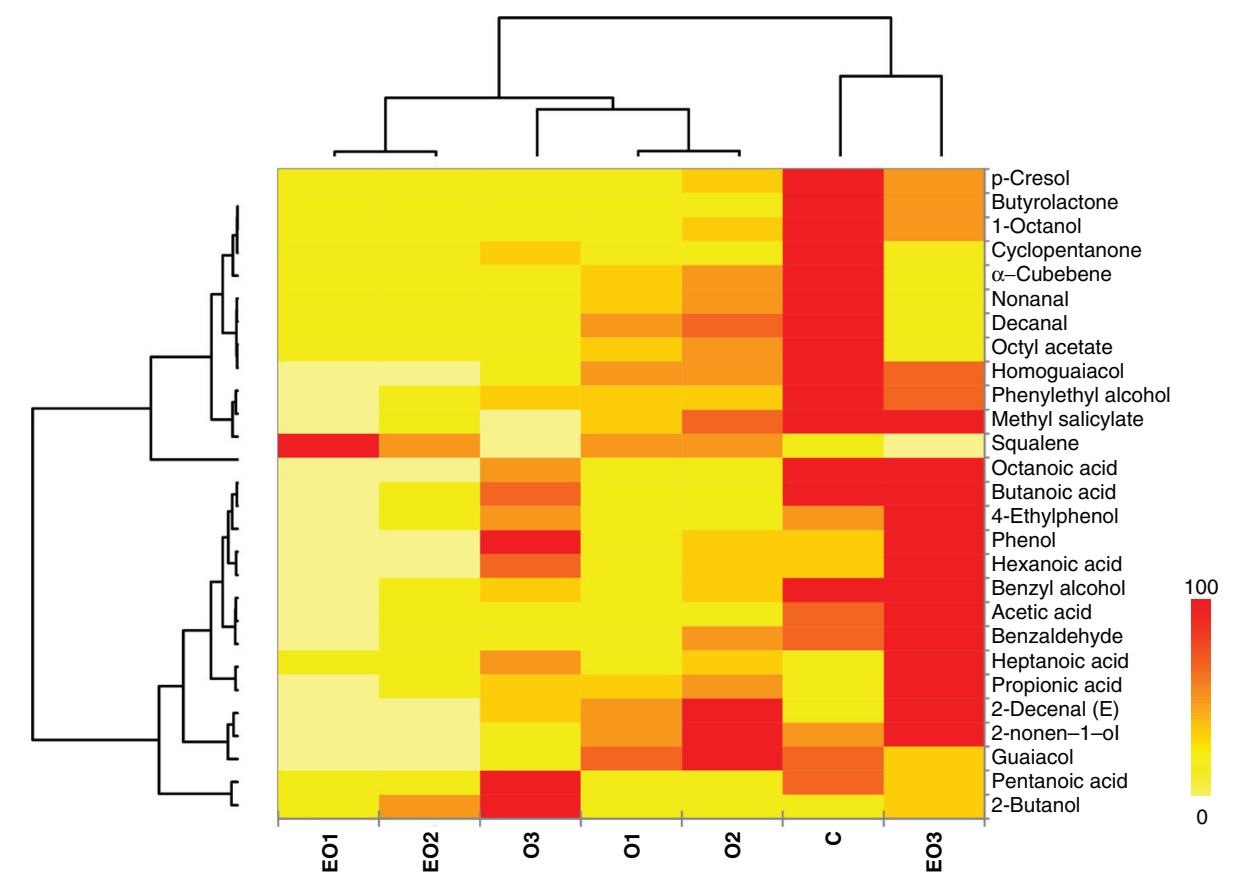

FIGURE 5. Distribution of volatile organic compounds (\% area) among trials at the end (day 190) of olive fermentations. The heat map plot depicts the relative percentage of each VOCs (variables clustering on the Y-axis) within each sample (X-axis clustering).

Abbreviations: C, control trial; O1, L. pentosus OM13 at $10^{4} \mathrm{CFU} / \mathrm{mL} ; \mathrm{EO} 1$, L. pentosus OM13 at $10^{4} \mathrm{CFU} / \mathrm{mL}+$ Acclimatization + Nutrient LBO2014 + Lactic acid; O2, L. pentosus OM13 at $10^{5} \mathrm{CFU} / \mathrm{mL} ; \mathrm{EO} 2$, L. pentosus OM13 at $10^{5} \mathrm{CFU} / \mathrm{mL}+$ Acclimatization + Nutrient LBO2014 + Lactic acid; O3, L. pentosus OM13 at $10^{6} \mathrm{CFU} / \mathrm{mL} ; \mathrm{EO} 3$, L. pentosus OM13 at $10^{6} \mathrm{CFU} / \mathrm{mL}+$ Acclimatization + Nutrient LBO2014 + Lactic acid.

The values for VOCs concentration are depicted by color intensity from yellow (lowest concentration) to red (highest concentration).

\subsection{Characterization and distribution of LAB}

One thousand, two hundred and twenty colonies were collected from the highest plated dilutions of cell suspensions. After a purification phase, they were subjected to microscopic inspection and all cultures with the shape morphology typical of lactobacilli were phenotypically investigated. Nine hundred and fifty-two cultures which resulted from Gram positive and catalase negative were considered presumptive LAB, and phenotypically grouped. Due to the high number of isolates, about $40 \%$ of the presumptive LAB cultures (381 isolates) were further grouped and selected on the basis of experimental trial and day of fermentation. All these selected cultures were subjected to RAPD-PCR analysis in order to identify the presence of the reference starter strain $L$. pentosus OM13 used for the inoculum. 76.8 and $65.6 \%$ of the isolates, showed polymorphic profiles with high levels $(>95 \%)$ of similarity with the reference strain OM13 from trials EO3 and EO2, respectively. In trial EO1, the percentage of isolates with a polymorphic profile similar to OM13 was $60.3 \%$. For the control C, a similar value $(74.6 \%)$ to those reported above was found. Although experimental trials EO3 and EO2 were fermented with the inoculum of starter OM13 at a concentration of 2 Log cycles lower than the control C, the starter strain OM13 was able to dominate indigenous LAB population as well as to promote a rapid decrease in $\mathrm{pH}$ by day 3 of fermentation. In experimental productions that did not provide for acclimatization of the OM13 strain $(\mathrm{O} 1, \mathrm{O} 2$ and $\mathrm{O} 3)$ the percentage of isolates with polymorphic profiles similar to the starter strain were between $59.8-70.2 \%$. Thus, in accordance with the results reported by Martorana et al., (2017a), the acclimatization of LAB starter cells has been confirmed once again as a method for improving starter culture growth during table olive manufacturing. Three isolates with RAPD profiles identical to the starter strain OM13 were also subjected to 16S rRNA gene sequencing which confirmed the species identity as L. pentosus (accession number MF577062).

Within the class of LAB, four strains were identified by using $16 \mathrm{~S}$ rRNA gene sequencing as L. plantarum (accession number MF577063) and seven strains as Pediococcus pentosaceus (accession number MF577063). These species were mainly found during the first sampling phases in trials O1, $\mathrm{O} 2$ and EO1; furthermore, the species $P$. pentosaceus was isolated until the end of fermentation (day 190) in trial $\mathrm{O} 1$. 
Approaches to improve the growth of the starter lactic acid bacterium OM13 during the early stages 9

TABLE 1. Concentrations of volatile organic compounds ( $\%$ area) at the end (day 190) of olive fermentations.

\begin{tabular}{|c|c|c|c|c|c|c|c|c|}
\hline Compounds & Control C & Trial 01 & Trial EO1 & Trial $\mathbf{O 2}$ & Trial EO2 & Trial 03 & Trial EO3 & $\begin{array}{c}\text { Statistical } \\
\text { significance }\end{array}$ \\
\hline 2-Butanol & $9.74 \pm 0.27^{\text {cd }}$ & $3.47 \pm 0.03^{\mathrm{de}}$ & $1.17 \pm 0.06^{\mathrm{e}}$ & $4.35 \pm 0.04^{\mathrm{de}}$ & $20.46 \pm 3.54^{\mathrm{b}}$ & $13.84 \pm 1.25^{\mathrm{bc}}$ & $62.04 \pm 5.87^{\mathrm{a}}$ & $* * *$ \\
\hline 2-nonen-1-ol & $0.55 \pm 0.03^{\mathrm{b}}$ & $0.55 \pm 0.11^{\mathrm{b}}$ & $0.15 \pm 0.02^{\mathrm{c}}$ & $0.89 \pm 0.07^{\mathrm{a}}$ & $0.17 \pm 0.06^{\mathrm{c}}$ & $0.85 \pm 0.09^{\mathrm{a}}$ & $0.28 \pm 0.04^{\mathrm{c}}$ & $* * *$ \\
\hline Nonanal & $4.01 \pm 0.14^{\mathrm{a}}$ & $1.38 \pm 0.09^{\mathrm{c}}$ & $0.16 \pm 0.01^{\mathrm{e}}$ & $1.72 \pm 0.06^{\mathrm{b}}$ & $0.35 \pm 0.09^{\mathrm{e}}$ & $0.84 \pm 0.11^{\mathrm{d}}$ & $0.26 \pm 0.02^{\mathrm{e}}$ & $* * *$ \\
\hline Acetic acid & $7.01 \pm 0.18^{\mathrm{b}}$ & $2.74 \pm 0.06^{\mathrm{cd}}$ & $0.34 \pm 0.11^{\mathrm{e}}$ & $3.43 \pm 0.33^{\mathrm{c}}$ & $2.06 \pm 0.36^{\mathrm{d}}$ & $12.00 \pm 0.98^{\mathrm{a}}$ & $3.45 \pm 0.11^{\mathrm{c}}$ & $* * *$ \\
\hline Octyl acetate & $0.84 \pm 0.06^{\mathrm{a}}$ & $0.27 \pm 0.01^{\mathrm{d}}$ & $0.06 \pm 0.00^{\mathrm{c}}$ & $0.35 \pm 0.02^{\mathrm{b}}$ & $0.04 \pm 0.00^{\mathrm{d}}$ & $0.00 \pm 0.00^{\mathrm{d}}$ & $0.04 \pm 0.00^{\mathrm{d}}$ & $* * *$ \\
\hline$\alpha$-Cubebene & $0.55 \pm 0.05^{\mathrm{a}}$ & $0.14 \pm 0.03^{\mathrm{c}}$ & $0.05 \pm 0.01^{\mathrm{d}}$ & $0.22 \pm 0.01^{\mathrm{b}}$ & $0.06 \pm 0.00^{\mathrm{d}}$ & $0.08 \pm 0.04^{\mathrm{cd}}$ & $0.08 \pm 0.02^{\mathrm{cd}}$ & $* * *$ \\
\hline Decanal & $1.27 \pm 0.11^{\mathrm{a}}$ & $0.51 \pm 0.04^{\mathrm{c}}$ & $0.05 \pm 0.02^{\mathrm{d}}$ & $0.69 \pm 0.06^{\mathrm{b}}$ & $0.11 \pm 0.02^{\mathrm{d}}$ & $0.13 \pm 0.03^{\mathrm{d}}$ & $0.04 \pm 0.02^{\mathrm{d}}$ & $* * *$ \\
\hline Benzaldehyde & $0.70 \pm 0.04^{\mathrm{b}}$ & $0.39 \pm 0.01^{\mathrm{c}}$ & $0.09 \pm 0.04^{\mathrm{d}}$ & $0.63 \pm 0.08^{b}$ & $0.17 \pm 0.11^{\mathrm{d}}$ & $1.13 \pm 0.11^{\mathrm{a}}$ & $0.25 \pm 0.01^{\mathrm{cd}}$ & $* * *$ \\
\hline Propionic acid & $3.12 \pm 0.22^{\mathrm{cd}}$ & $8.55 \pm 0.81^{\mathrm{b}}$ & $0.83 \pm 0.14^{\mathrm{d}}$ & $10.88 \pm 2.33^{\mathrm{b}}$ & $7.43 \pm 0.78^{\mathrm{bc}}$ & $23.72 \pm 3.33^{\mathrm{a}}$ & $10.44 \pm 1.44^{\mathrm{b}}$ & $* * *$ \\
\hline 1-Octanol & $1.39 \pm 0.08^{\mathrm{a}}$ & $0.24 \pm 0.01^{\mathrm{d}}$ & $0.04 \pm 0.00^{\mathrm{f}}$ & $0.36 \pm 0.01^{\mathrm{c}}$ & $0.07 \pm 0.00^{\text {ef }}$ & $0.60 \pm 0.05^{\mathrm{b}}$ & $0.15 \pm 0.00^{\mathrm{de}}$ & $* * *$ \\
\hline Butyrolactone & $0.97 \pm 0.07^{\mathrm{a}}$ & $0.10 \pm 0.04^{\mathrm{cd}}$ & $0.04 \pm 0.00^{\mathrm{d}}$ & $0.19 \pm 0.01^{\mathrm{c}}$ & $0.07 \pm 0.00^{\mathrm{d}}$ & $0.35 \pm 0.07^{\mathrm{b}}$ & $0.13 \pm 0.00^{\mathrm{cd}}$ & $* * *$ \\
\hline Butanoic acid & $1.45 \pm 0.09^{\mathrm{ab}}$ & $0.21 \pm 0.07^{\mathrm{cd}}$ & $0.10 \pm 0.01^{\mathrm{d}}$ & $0.53 \pm 0.04^{\mathrm{c}}$ & $0.27 \pm 0.03^{\mathrm{cd}}$ & $1.74 \pm 0.26^{\mathrm{a}}$ & $1.36 \pm 0.12^{\mathrm{b}}$ & $* * *$ \\
\hline 2-Decenal (E) & $0.11 \pm 0.01^{\mathrm{cd}}$ & $0.21 \pm 0.05^{\mathrm{b}}$ & $0.06 \pm 0.00^{\mathrm{d}}$ & $0.31 \pm 0.04^{\mathrm{a}}$ & $0.07 \pm 0.02^{\mathrm{d}}$ & $0.31 \pm 0.03^{\mathrm{a}}$ & $0.19 \pm 0.02^{\mathrm{bc}}$ & $* * *$ \\
\hline Pentanoic acid & $0.69 \pm 0.08^{\mathrm{b}}$ & $0.10 \pm 0.02^{\mathrm{d}}$ & $0.03 \pm 0.00^{\mathrm{e}}$ & $0.18 \pm 0.03$ & $0.05 \pm 0.01^{\mathrm{d}}$ & $0.30 \pm 0.02^{\mathrm{c}}$ & $1.25 \pm 0.01^{\mathrm{a}}$ & $* * *$ \\
\hline Methyl salicylate & $0.41 \pm 0.02^{\mathrm{a}}$ & $0.19 \pm 0.01^{\mathrm{a}}$ & $0.04 \pm 0.02^{\mathrm{a}}$ & $0.34 \pm 0.02^{\mathrm{a}}$ & $0.09 \pm 0.02^{\mathrm{a}}$ & $0.38 \pm 0.38^{\mathrm{a}}$ & $0.05 \pm 0.00^{\mathrm{a}}$ & N.S. \\
\hline Hexanoic acid & $0.34 \pm 0.02^{\mathrm{bc}}$ & $0.27 \pm 0.05^{\mathrm{cd}}$ & $0.08 \pm 0.04^{\mathrm{e}}$ & $0.35 \pm 0.10^{\mathrm{bc}}$ & $0.13 \pm 0.02^{\mathrm{de}}$ & $0.61 \pm 0.06^{\mathrm{a}}$ & $0.43 \pm 0.05^{\mathrm{b}}$ & $* * *$ \\
\hline Guaiacol & $0.97 \pm 0.14^{\mathrm{ab}}$ & $1.07 \pm 0.03^{\mathrm{a}}$ & $0.04 \pm 0.00^{\mathrm{e}}$ & $1.23 \pm 0.06^{\mathrm{a}}$ & $0.14 \pm 0.03^{\mathrm{de}}$ & $0.74 \pm 0.23^{\mathrm{bc}}$ & $0.44 \pm 0.06^{\mathrm{cd}}$ & $* * *$ \\
\hline Cyclopentanone & $0.74 \pm 0.06^{\mathrm{a}}$ & $0.02 \pm 0.00^{\mathrm{d}}$ & $0.10 \pm 0.02^{\mathrm{bc}}$ & $0.07 \pm 0.00^{\mathrm{bcd}}$ & $0.05 \pm 0.00^{\mathrm{cd}}$ & $0.06 \pm 0.00^{\mathrm{cd}}$ & $0.13 \pm 0.00 \mathrm{~b}$ & $* * *$ \\
\hline Benzyl alcohol & $2.12 \pm 0.20^{\mathrm{b}}$ & $1.04 \pm 0.04^{\mathrm{c}}$ & $0.09 \pm 0.03^{\mathrm{e}}$ & $1.28 \pm 0.10^{\mathrm{c}}$ & $0.61 \pm 0.06^{\mathrm{d}}$ & $2.60 \pm 0.21^{\mathrm{a}}$ & $1.18 \pm 0.08^{\mathrm{c}}$ & $* * *$ \\
\hline Phenylethyl alcohol & $3.77 \pm 0.17^{\mathrm{a}}$ & $1.56 \pm 0.14^{\mathrm{c}}$ & $0.12 \pm 0.01^{\mathrm{e}}$ & $1.74 \pm 0.16^{\mathrm{c}}$ & $0.84 \pm 0.08^{\mathrm{d}}$ & $2.53 \pm 0.18^{\mathrm{b}}$ & $1.54 \pm 0.36^{\mathrm{c}}$ & $* * *$ \\
\hline Homoguaiacol & $32.89 \pm 1.86^{\mathrm{a}}$ & $20.18 \pm 0.90^{\mathrm{b}}$ & $2.43 \pm 0.24^{\mathrm{d}}$ & $21.43 \pm 1.88^{\mathrm{b}}$ & $7.09 \pm 0.66^{\mathrm{cd}}$ & $24.57 \pm 2.63^{\mathrm{b}}$ & $12.40 \pm 4.22^{\mathrm{c}}$ & $* * *$ \\
\hline Heptanoic acid & $0.00 \pm 0.00^{\mathrm{d}}$ & $0.07 \pm 0.01^{\mathrm{cd}}$ & $0.05 \pm 0.02^{\mathrm{d}}$ & $0.14 \pm 0.06^{\mathrm{bc}}$ & $0.06 \pm 0.00^{\mathrm{cd}}$ & $0.48 \pm 0.05^{\mathrm{a}}$ & $0.19 \pm 0.00^{\mathrm{b}}$ & $*$ \\
\hline Phenol & $0.41 \pm 0.04^{\mathrm{b}}$ & $0.27 \pm 0.03^{\mathrm{cd}}$ & $0.06 \pm 0.03^{\mathrm{e}}$ & $0.38 \pm 0.05^{\mathrm{bc}}$ & $0.14 \pm 0.00^{\mathrm{de}}$ & $0.67 \pm 0.06^{\mathrm{a}}$ & $0.62 \pm 0.08^{\mathrm{a}}$ & $* * *$ \\
\hline Octanoic acid & $0.46 \pm 0.05^{\mathrm{a}}$ & $0.12 \pm 0.02^{\mathrm{c}}$ & $0.08 \pm 0.03^{\mathrm{c}}$ & $0.18 \pm 0.09^{\mathrm{c}}$ & $0.08 \pm 0.00^{\mathrm{c}}$ & $0.49 \pm 0.04^{\mathrm{a}}$ & $0.33 \pm 0.02^{\mathrm{b}}$ & $* *$ \\
\hline$p$-Cresol & $0.84 \pm 0.07^{\mathrm{a}}$ & $0.15 \pm 0.01^{\mathrm{cd}}$ & $0.05 \pm 0.02^{\mathrm{d}}$ & $0.24 \pm 0.12^{\mathrm{bc}}$ & $0.09 \pm 0.00^{\mathrm{cd}}$ & $0.33 \pm 0.02^{\mathrm{b}}$ & $0.15 \pm 0.01^{\mathrm{cd}}$ & $* * *$ \\
\hline 4-Ethylphenol & $2.54 \pm 0.10^{\mathrm{b}}$ & $0.95 \pm 0.08^{\mathrm{c}}$ & $0.17 \pm 0.09^{\mathrm{c}}$ & $1.03 \pm 0.21^{\mathrm{c}}$ & $1.17 \pm 0.12^{\mathrm{c}}$ & $5.61 \pm 0.86^{\mathrm{a}}$ & $2.58 \pm 0.42^{b}$ & $* * *$ \\
\hline Squalene & $22.11 \pm 2.30^{\mathrm{d}}$ & $55.25 \pm 2.56^{\mathrm{bc}}$ & $93.52 \pm 5.25^{\mathrm{a}}$ & $46.86 \pm 3.77^{\mathrm{c}}$ & $58.13 \pm 6.11^{\mathrm{b}}$ & $5.04 \pm 0.21^{\mathrm{e}}$ & $0.00 \pm 0.00^{\mathrm{e}}$ & $* * *$ \\
\hline
\end{tabular}

Abbreviations: C, control trial; O1, L. pentosus OM13 at $10^{4} \mathrm{CFU} / \mathrm{mL}$; EO1, L. pentosus OM13 at $10^{4} \mathrm{CFU} / \mathrm{mL}+$ Acclimatization + Nutrient LBO2014+ Lactic acid; O2, L. pentosus OM13 at $10^{5} \mathrm{CFU} / \mathrm{mL} ; \mathrm{EO} 2$, L. pentosus OM13 at $10^{5} \mathrm{CFU} / \mathrm{mL}+$ Acclimatization + Nutrient LBO2014+ Lactic acid; O3, L. pentosus OM13 at $10^{6} \mathrm{CFU} / \mathrm{mL}$; EO3, L. pentosus OM13 at $10^{6} \mathrm{CFU} / \mathrm{mL}+$ Acclimatization + Nutrient LBO2014+ Lactic acid. All determinations were carried out in triplicate and mean value \pm standard deviation reported.

Data within a line followed by the same letter are not significantly different according to Tukey's test.

ANOVA $p$ value: ${ }^{*}, p<0.05^{* *}, p<0.01 ;{ }^{* * *}, p<0.001$, N.S., not significant

All LAB species reported above are normally isolated during the fermentation of table olives as already reported by Martorana et al., (2016, 2017a). These species represent part of the microbial ecology of table olive fermentation and might significantly contribute to the acidification and aroma of the final product. The level of species diversity of LAB was not high since all experimental trials were inoculated with the starter strain OM13. Generally, high values of microbial diversity have been found during spontaneous fermentation, as previously reported by several authors (Hurtado et al., 2008), as well as described for food fermentations such as wine, cheese and salami (Moschetti et al., 2016; Gaglio et al., 2016a, b).
Explorative multivariate analysis has been widely applied to monitor the microbiological and chemical changes during experimental productions of table olives (Rodríguez-Gómez et al., 2012; Martorana et al., 2015, 2016, 2017b). In particular, the clustering analysis combined with graphical representation by a heat map plot is a useful method to depict a large data set and underline the main differences among experimental trials.

\subsection{VOCs in fermented olives}

Volatile organic compounds might significantly affect the organoleptic characteristics of fermented table olives due to the enzymes produced by microbial 
populations that occur during the entire manufacturing process (Sabatini and Marsilio 2008). In the present work, the VOC profile has been determined on table olives at the end of the fermentation period (day 190), as shown in Table 1. A total of 27 compounds belonging to groups of aldehydes, ketones, alcohols, alkanes and furans were identified. High concentrations of 2-butanol, acetic and propionic acids, homoguaiacol and 4-ethylphenol were found in trials EO3, EO2 and O3. The chemical squalene reached its highest concentration in trials EO1, EO2 and $\mathrm{O} 1$.

However, in order to better investigate the effect of experimental treatments on the VOC composition and concentration of final products, the data set of VOCs was also subjected to a multivariate statistical analysis and the results are illustrated by heat map plot (Figure 5). Interestingly, all the trials were grouped into two mega-clusters and the VOC profile of trial EO3 was closely related to that of control C. On the other hand, all remaining trials were grouped into one mega-cluster where trials EO1 and $\mathrm{EO} 2$ were significantly separated from trials $\mathrm{O} 1, \mathrm{O} 2$ and $\mathrm{O} 3$. Thus, the experimental procedures based on starter cell acclimatization and the addition of nutrients and lactic acid were confirmed to be a effective strateies to differentiate the VOC profiles of fermented olives and to confirm the results already published by Martorana et al., (2017a).

\subsection{Sensory attributes of fermented olives}

The olive samples collected at the end of the fermentation process (day 190) were subjected to a sensory analysis by 12 trained panelists who identified a total of 16 attributes as reported in Table 2.

Statistically significant differences $(\mathrm{p}<0.05)$ among experimental olives were found for several descriptors. Olives from trials EO3 and EO2 showed the highest scores for odor and flavor complexities and green olive aroma. Although the experimental trials EO3 and EO2 were performed by inoculating the OM13 starter at a level significantly lower than those of control $\mathrm{C}$, the sensory profiles of experimental olives EO3 and EO2 were positively appreciated by panelists and reached high scores of overall acceptability. Similar values were obtained by Martorana et al., (2017a) who showed the effects of cell acclimatization and nutrient supplements on the sensory characteristics of fermented olives for the first time.

The sensory profiles of fermented olives are significantly affected by diversity and the concentration of many chemicals, in particular organic acids, phenols and VOCs. The presence of these

TABLE 2. Sensory scores for olives collected at the end (day 190) of fermentation.

\begin{tabular}{|c|c|c|c|c|c|c|c|c|c|}
\hline \multirow[b]{2}{*}{ Descriptors } & \multicolumn{7}{|c|}{ Trials } & \multirow[b]{2}{*}{ SEM } & \multirow{2}{*}{$\begin{array}{c}\text { Statistical } \\
\text { significance }\end{array}$} \\
\hline & $\mathrm{C}$ & 01 & EO1 & O2 & EO2 & $\mathbf{O 3}$ & EO3 & & \\
\hline Green color intensity & $6.22^{\mathrm{ab}}$ & $6.20^{\mathrm{ab}}$ & $6.21^{\mathrm{ab}}$ & $6.05^{\mathrm{b}}$ & $6.45^{\mathrm{a}}$ & $6.15^{\mathrm{ab}}$ & $6.37^{\mathrm{ab}}$ & 0.03 & $*$ \\
\hline Brightness & $5.30^{\mathrm{ab}}$ & $4.62^{\mathrm{c}}$ & $5.00^{\mathrm{b}}$ & $5.16^{\mathrm{ab}}$ & $5.40^{\mathrm{a}}$ & $5.15^{\mathrm{ab}}$ & $5.10^{\mathrm{ab}}$ & 0.06 & $* *$ \\
\hline Green olive aroma & $7.02^{\mathrm{b}}$ & $6.11^{\mathrm{c}}$ & $6.80^{\mathrm{b}}$ & $6.11^{\mathrm{c}}$ & $6.87^{\mathrm{b}}$ & $6.27^{\mathrm{c}}$ & $7.40^{\mathrm{a}}$ & 0.11 & $* * *$ \\
\hline Complexity (odor) & $7.77^{\mathrm{ab}}$ & $7.20^{\mathrm{d}}$ & $7.02^{\text {cd }}$ & $7.35^{\mathrm{cd}}$ & $7.50^{\mathrm{bc}}$ & $7.35^{\mathrm{cd}}$ & $8.10^{\mathrm{a}}$ & 0.08 & $* * *$ \\
\hline Off-odors & $1.00^{\mathrm{b}}$ & $1.89^{\mathrm{a}}$ & $1.78^{\mathrm{a}}$ & $1.60^{\mathrm{a}}$ & $1.00^{\mathrm{b}}$ & $1.00^{\mathrm{b}}$ & $1.00^{\mathrm{b}}$ & 0.09 & $* * *$ \\
\hline Crispness & $5.77^{\mathrm{a}}$ & $5.64^{\mathrm{a}}$ & $5.82^{\mathrm{a}}$ & $5.64^{\mathrm{a}}$ & $5.90^{\mathrm{a}}$ & $5.75^{\mathrm{a}}$ & $5.88^{\mathrm{a}}$ & 0.03 & N.S. \\
\hline Easy stone & $6.22^{\mathrm{a}}$ & $5.50^{\mathrm{c}}$ & $5.55^{\mathrm{c}}$ & $5.80^{\mathrm{bc}}$ & $6.04^{\mathrm{ab}}$ & $6.12^{\mathrm{ab}}$ & $6.04^{\mathrm{ab}}$ & 0.06 & $* *$ \\
\hline Juicy & $7.35^{\mathrm{a}}$ & $7.11^{\mathrm{bc}}$ & $7.28^{\mathrm{ab}}$ & $7.01^{\mathrm{c}}$ & $7.11^{\mathrm{bc}}$ & $7.20^{\mathrm{abc}}$ & $7.21^{\mathrm{abc}}$ & 0.03 & $*$ \\
\hline Sweet & $4.60^{\mathrm{ab}}$ & $4.15^{\mathrm{c}}$ & $4.30^{\mathrm{bc}}$ & $4.70^{\mathrm{a}}$ & $4.50^{\mathrm{ab}}$ & $4.50^{\mathrm{ab}}$ & $4.57^{\mathrm{ab}}$ & 0.04 & $*$ \\
\hline Sour & $4.50^{\mathrm{ab}}$ & $4.26^{\mathrm{b}}$ & $4.53^{\mathrm{a}}$ & $4.52^{\mathrm{a}}$ & $4.54^{\mathrm{a}}$ & $4.57^{\mathrm{a}}$ & $4.47^{\mathrm{ab}}$ & 0.03 & $*$ \\
\hline Bitter & $2.45^{\mathrm{d}}$ & $3.12^{\mathrm{a}}$ & $3.00^{\mathrm{ab}}$ & $2.80^{\mathrm{bc}}$ & $2.80^{\mathrm{bc}}$ & $2.70^{\text {cd }}$ & $2.60^{\mathrm{cd}}$ & 0.05 & $* *$ \\
\hline Salt & $3.84^{\mathrm{a}}$ & $3.15^{\mathrm{b}}$ & $3.27^{\mathrm{b}}$ & $3.24^{\mathrm{b}}$ & $3.70^{\mathrm{a}}$ & $3.33^{\mathrm{b}}$ & $3.74^{\mathrm{a}}$ & 0.06 & $* *$ \\
\hline Complexity (taste) & $7.88^{\mathrm{ab}}$ & $6.50^{\mathrm{e}}$ & $7.30^{\mathrm{c}}$ & $6.95^{\mathrm{d}}$ & $7.68^{\mathrm{b}}$ & $7.10^{\mathrm{cd}}$ & $8.01^{\mathrm{a}}$ & 0.11 & $* * *$ \\
\hline Astringent & $2.12^{\mathrm{c}}$ & $2.66^{\mathrm{ab}}$ & $2.35 b^{c}$ & $2.77^{\mathrm{a}}$ & $2.52^{\mathrm{ab}}$ & $2.34^{\mathrm{bc}}$ & $2.12^{\mathrm{c}}$ & 0.06 & $* *$ \\
\hline Off-flavors & $1.00^{\mathrm{b}}$ & $1.30^{\mathrm{ab}}$ & $1.21^{\mathrm{ab}}$ & $1.45^{\mathrm{a}}$ & $1.00^{\mathrm{b}}$ & $1.17^{\mathrm{ab}}$ & $1.00^{\mathrm{b}}$ & 0.04 & $*$ \\
\hline Overall acceptability & $7.85^{\mathrm{b}}$ & $7.15^{\mathrm{c}}$ & $7.60^{\mathrm{b}}$ & $7.20^{\mathrm{c}}$ & $7.70^{\mathrm{b}}$ & $7.74^{\mathrm{b}}$ & $8.35^{\mathrm{a}}$ & 0.09 & $* * *$ \\
\hline
\end{tabular}

Results indicate mean value of each sensorial attribute evaluated by 12 trained panelists.

Data within a line followed by the same letter are not significantly different according to Tukey's test.

ANOVA $p$ value: $* . p<0.05^{* *} . p<0.01 ; * *$. $p<0.001$; N.S., not significant.

Abbreviations: C, control trial; O1, L. pentosus OM13 at $10^{4} \mathrm{CFU} / \mathrm{mL}$; EO1, L. pentosus OM13 at $10^{4} \mathrm{CFU} / \mathrm{mL}+$ Acclimatization + Nutrient LBO2014 + Lactic acid; O2, L. pentosus OM13 at $10^{5} \mathrm{CFU} / \mathrm{mL} ; \mathrm{EO} 2$, L. pentosus OM13 at $10^{5} \mathrm{CFU} / \mathrm{mL}+$ Acclimatization + Nutrient LBO2014 + Lactic acid; O3, L. pentosus OM13 at $10^{6} \mathrm{CFU} / \mathrm{mL} ; \mathrm{EO} 3$, L. pentosus OM13 at $10^{6} \mathrm{CFU} / \mathrm{mL}+$ Acclimatization + Nutrient LBO2014 + Lactic acid. 
chemicals compounds in the final product is influenced by the growth of the microbial population and by the diversity of LAB strain during the fermentation process (Martorana et al., 2015).

The presence of off-odors and off-flavors (such as fecal, putrid, etc.) in fermented olives is closely related to the growth of spoilage microorganisms which belong to enterobacteria and pseudomonads groups (Randazzo et al., 2017). Furthermore, the bitter taste, which is not usually accepted by consumers, might be improved by intense growth of $\mathrm{LAB}$, which are able to degrade phenols into other less-bitter compounds (Marsilio et al., 2006).

The results from the sensory analysis were also subjected to a statistical multivariate analysis through the construction of an external preference map, as shown in Figure 6. This graphical representation included the position of the ideal point and iso-preference curves for the vectorial model related to six different clusters. By analysis of the model selection, cluster 2 was recognized as the ideal point type and correlated with values of $8.16 \mathrm{~F} 1$ and 13.11 F2 axes. The experimental trials EO3, EO2 and control $\mathrm{C}$ were clustered into one main group that was significantly correlated with the ideal point cluster 2 since these trials were preferred by $60-80 \%$ of panelists. On the contrary, the experimental olives from trial O1, which was not subjected to cell

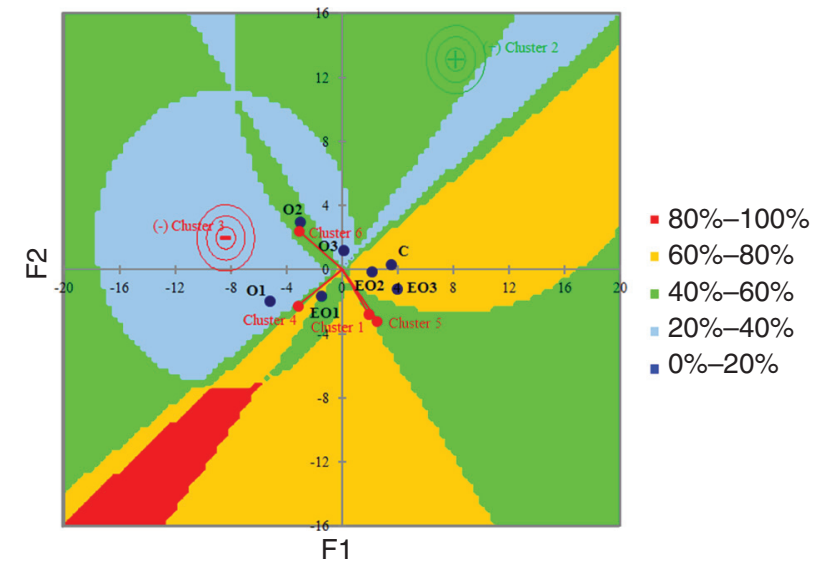

FIGURE 6. Contour plot based on results from the sensory analysis performed on table olives at the end of fermentation (day 190).

Abbreviations: C, control trial; O1, L. pentosus OM13 at $10^{4} \mathrm{CFU} / \mathrm{mL}$; EO1, L. pentosus OM13 at $10^{4} \mathrm{CFU} / \mathrm{mL}+$ Acclimatization + Nutrient LBO2014+ Lactic acid; O2, L. pentosus OM13 at $10^{5} \mathrm{CFU} / \mathrm{mL} ; \mathrm{EO} 2, L$. pentosus $\mathrm{OM} 13$ at $10^{5} \mathrm{CFU} / \mathrm{mL}+$ Acclimatization + Nutrient LBO2014 + Lactic acid; O3, L. pentosus OM13 at $10^{6} \mathrm{CFU} / \mathrm{mL}$; EO3, $L$. pentosus $\mathrm{OM} 13$ at $10^{6} \mathrm{CFU} / \mathrm{mL}+$ Acclimatization + Nutrient LBO2014+ Lactic acid.

Legend: values (\%) of preferences and satisfaction for table olive samples shown by judges.

Preferences and satisfaction (\%) for table olive samples.

Clusters are based on the segmentation of the judges by groups of similar preferences. acclimatization or supplement addition, was closely related to cluster 3 , identified as an anti-ideal point type. Furthermore, the olives from trial $\mathrm{O} 1$ were preferred by only $20-40 \%$ of the judges.

\section{CONCLUSIONS}

The present study evaluated the effect of the acclimatization of LAB cell and supplement (nutrient and lactic acid) addition to improve the growth and dominance of the LAB starter during olive fermentation.

The microbiological results confirmed significant and positive effects of these innovative procedures on the ability of starter OM13 to dominate indigenous microbial populations during the fermentation of table olives. A significant effect was also found in terms of acidification kinetics within the first week of fermentation.

Furthermore, the cell acclimatization procedure was found to improve the dominance of starter OM13 even just after the inoculum into brine, when its population levels were $2 \mathrm{Log}$ cycles lower than that commonly reached during standard fermentation.

The treatment EO3 showed characteristics similar to those obtained for trial $\mathrm{C}$. This trend was also confirmed by the results from the sensory analysis, since trials $\mathrm{C}, \mathrm{EO} 2$ and $\mathrm{EO} 3$ showed high values of preference and satisfaction, as well as by the PCA and $\mathrm{AHC}$ results, which indicated that trials $\mathrm{C}$ and EO3 were closely related to the population of LAB.

\section{ACKNOWLEDGMENTS}

This work was financially supported by P.O.N. RICERCA E COMPETIVITA' 2007-2013. Progetto "Di.Me.Sa."- Valorizzazione di prodotti tipici della Dieta Mediterranea e loro impiego a fini salutistici e nutraceutici. Code of Project: PON02_00667 -PON02_00451_3361785.

The authors wish to thank the enterprise Geolive Belice S.A.S. and Dr. Francesco La Croce (Olive da tavola Castelvetrano, Trapani, Italy) for its technical support during the fermentation process of drupes, the company LALLEMAND Inc. (1620 rue Prefontaine Montreal Quebec H1W 2N8, Canada) for its significant support to lyophilize L. pentosus OM13 strains, and to produce nutrient supplements, and Rosario Prestianni for his support in microbiological and chemical analyses.

The authors are also grateful to the Dr. Specht Gordon for proof-reading the final version of English.

\section{REFERENCES}

Aponte M, Blaiotta G, La Croce F, Mazzaglia A, Farina V, Settanni L, Moschetti G. 2012. Use of selected autochthonous lactic acid bacteria for Spanish- style table olive fermentation. Food Microbiol. 30, 8-16. https://doi.org/ 10.1016/j.fm.2011.10.005 
Arroyo-López FN, Querol A, Bautista-Gallego J, GarridoFernández A. 2008. Role of yeasts in table olive production. Int. J. Food Microbiol. 128, 189-196. https://doi.org/ 10.1016/j.ijfoodmicro.2008.08.018

Castro A de, Montaño A, Casado FJ, Sánchez A H, Rejano L. 2002. Utilization of Enterococcus casseliflavus and Lactobacillus pentosus as starter cultures for Spanish-style green olive fermentation. Food Microbiol. 19(6), 637-644. https://doi.org/10.1006/fmic.2002.0466

Chasseriaud L, Krieger-Weber S, Déléris-Bou M, Sieczkowski N, Jourdes M, Teissedre PL, Claisse 0, Lonvaud-Funel A. 2015. Hypotheses on the effects of enological tannins and total red wine phenolic compounds on Oenococcus oeni. Food Microbiol. 52, 131-137. https://doi.org/10.1016/j.fm. 2015.07.002

Corona O, Alfonzo A, Ventimiglia G, Nasca A, Francesca N, Martorana A, Moschetti G, Settanni L. 2016. Industrial application of selected lactic acid bacteria isolated from local semolinas for typical sourdough bread production. Food Microbiol. 59, 43-56. https://doi.org/10.1016/j.fm.2016.05.006

Francesca N, Barbera M, Martorana A, Saiano F, Gaglio R, Aponte M, Moschetti G, Settanni L. 2016. Optimised method for the analysis of phenolic compounds from caper (Capparis spinosa L.) berries and monitoring of their changes during fermentation. Food Chem. 196, 1172-1179. https://doi.org/10.1016/j.foodchem.2015.10.045

Gaglio R, Scatassa ML, Cruciata M, Miraglia V, Corona O, Di Gerlando R, Portolano B, Moschetti G, Settanni L. 2014. In vivo application and dynamics of lactic acid bacteria for the four-season production of Vastedda-like cheese. Int. J. Food Microbiol. 177, 37-48. https://doi.org/10.1016/j. ijfoodmicro.2014.02.007

Gaglio R, Francesca N, Maniaci G, Corona O, Alfonzo A, Giosuè C, Di Noto A, Cardamone C, Sardina MT, Portolano B, Alabiso, M. 2016a. Valorization of indigenous dairy cattle breed through salami production. Meat Sci. 114, 58-68. https://doi.org/10.1016/j.meatsci.2015.12.014

Gaglio R, Cruciata M, Di Gerlando R, Scatassa ML, Cardamone C, Mancuso I, Sardina MT, Moschetti G, Portolano B, Settanni L. 2016b. Microbial activation of wooden vats used for traditional cheese production and evolution of the neo-formed biofilms. Appl. Environ. Microb. 82, 585-595. https://doi.org/10.1128/AEM.02868-15

Gaglio R, Francesca N, Di Gerlando R, Mahony J, De Martino S, Stucchi C, Moschetti G, Settanni L. 2017. Enteric bacteria of food ice and their survival in alcoholic beverages and soft drinks. Food Microbiol. 67, 17-22.

Garrido-Fernández A, Fernández Díez MJ, Adams MR. 1997. Table Olives, Production and Processing. Champman and Hall, London.

Holzapfel WH. 2002. Appropriate starter culture technologies for small-scale fermentation in developing countries. Int. J. Food Microbiol. 75, 197-212. https://doi.org/10.1016/ S0168-1605(01)00707-3

Hurtado A, Reguant C, Esteve-Zarzoso B, Bordons A, Rozès N. 2008. Microbial population dynamics during the processing of Arbequina table olives. Food Res. Int. 41, 738-744. https://doi.org/10.1016/j.foodres.2008.05.007

Hurtado A, Reguant C, Bordons A, Rozès N. 2012. Lactic acid bacteria from fermented table olives. Food Microbiol. 31, 1-8. https://doi.org/10.1016/j.fm.2012.01.006

Jervis SM, Guthrie B, Guo G, Worch T, Hasted A, Drake MA. 2016. Comparison of Preference Mapping Methods on Commodity Foods with Challenging Groups of LowVariance Attributes: Sliced Whole Wheat Sandwich Bread Example. J. Sens. Stud. 31, 34 49. https://doi.org/10.1111/ joss. 12188

Kontkanen D, Inglis DL, Pickering GJ, Reynolds A. 2004. Effect of yeast inoculation rate, acclimatization, and nutrient addition on icewine fermentation. Am. J. Enol. Viticult. 55, 363-370.

Marsilio V, d'Andria R, Lanza B, Russi F, Iannucci E, Lavini A, Morelli G. 2006. Effect of irrigation and lactic acid bacteria inoculants on the phenolic fraction, fermentation and sensory characteristics of olive (Olea europaea L. cv. Ascolana tenera) fruits. J. Sci. Food Agr. 86, 1005-1013. https://doi. org/10.1002/jsfa. 2449

Martorana A, Alfonzo A, Settanni L, Corona O, La Croce F, Caruso T, Moschetti G, Francesca N. 2015. An innovative method to produce green table olives based on "pied de cuve" technology. Food Microbiol. 50, 126-140. https://doi. org/10.1016/j.fm.2015.03.008

Martorana A, Alfonzo A, Settanni L, Corona O, La Croce F, Caruso T, Moschetti G, Francesca N. 2016. Effect of the mechanical harvest of drupes on the quality characteristics of green fermented table olives. J. Sci. Food Agr. 96, 2004-2017. https://doi.org/10.1002/jsfa.7311

Martorana A, Alfonzo A, Gaglio R, Settanni L, Corona O, La Croce F, Vagnoli P, Caruso T, Moschetti G, Francesca N. 2017a. Evaluation of different conditions to enhance the performances of Lactobacillus pentosus OM13 during industrial production of Spanish-style table olives. Food Microbiol. 61, 150-158. https://doi.org/10.1016/j. fm.2016.08.007

Martorana A, Di Miceli C, Alfonzo A, Settanni L, Gaglio R, Caruso T, Moschetti G, Francesca N. 2017b. Effects of irrigation treatments on the quality of table olives produced with the Greek-style process. Ann. Microbiol. 67, 37-48. https://doi.org/10.1007/s13213-016-1234-2

Moschetti G, Corona O, Gaglio R, Squadrito M, Parrinello A, Settanni L, Barone E, Francesca N. 2016. Use of fortified pied de cuve as an innovative method to start spontaneous alcoholic fermentation for red winemaking. Aust. J. Grape Wine R. 22, 36-45. https://doi.org/10.1111/ajgw.12166

Oliveira T, Ramalhosa E, Nunes L, Pereira JA, Colla E, Pereira EL. 2017. Probiotic potential of indigenous yeasts isolated during the fermentation of table olives from Northeast of Portugal. Innov. Food Sci. Emerg. In press. https://doi. org/10.1016/j.ifset.2017.06.003

Panagou EZ, Tassou CC, Katsaboxakis CZ. 2003. Induced lactic acid fermentation of untreated green olives of the Conservolea cultivar by Lactobacillus pentosus. J. Sci. Food Agr. 83, 667-674. https://doi.org/10.1002/jsfa.1336

Randazzo CL, Todaro A, Pino A, Pitino I, Corona O, Caggia C. 2017. Microbiota and metabolome during controlled and spontaneous fermentation of Nocellara Etnea table olives. Food Microbiol. 65, 136-148. https://doi.org/10.1016/j.fm. 2017.01.022

Rodríguez-Gómez F, Romero-Gil V, Bautista-Gallego J, GarridoFernández A, Arroyo López FN. 2012. Multivariate analysis to discriminate yeasts strains with technological applications in table olive processing. World J. Microb. Biot. 28, 1761-1770. https://doi.org/10.1007/s11274-011-0990-1

Sabatini N, Marsilio V. 2008. Volatile compounds in table olives (Olea europaea L., Nocellara del Belice cultivar). Food Chem. 107, 1522-1528. https://doi.org/10.1016/j.foodchem. 2007.10 .008

Servili M, Settanni L, Veneziani G, Esposto S, Massitti O, Taticchi A, Urbani S, Montedoro GF, Corsetti A. 2006. The use of Lactobacillus pentosus $1 \mathrm{MO}$ to shorten the debittering process time of black table olives $(\mathrm{Cv}$. Itrana and Leccino): a pilot-scale application. J. Agr. Food Chem. 54, 3869-3875. https://doi.org/10.1021/jf053206y

Teixeira P, Castro H, Kirby R. 1995. Spray drying as a method for preparing concentrated cultures of Lactobacillus bulgaricus. J. Appl. Microbiol. 78, 456-462. https://doi.org/ 10.1111/j.1365-2672.1995.tb03433.x

Torriani S, Felis GE, Dellaglio F. 2001. Differentiation of Lactobacillus plantarum, L. pentosus, and L. paraplantarum by recA gene sequence analysis and multiplex PCR assay with recA gene-derived primers. Appl. Environ. Microb. 67, 3450 3454. https://doi.org/10.1128/AEM.67.8.3450-3454.2001

Weisburg WG, Barns SM, Pelletier DA, Lane DJ. 1991. 16S ribosomal DNA amplification for phylogenetic study. J. Bacteriol. 173, 697-703. 